cardial Damage Compared to Heart Failure Patients with Preserved Renal Function. Cardiorenal Medicine, 4 (3-4), 257-268. doi: http://doi.org/10.1159/000368375

[20] Abraham, W. T., Shrier, R. W. (1996). Renal salt and Water Handling in Congestive heart Failure. Congestive Heart Failure. New York: Springer-Verland, 161-173.

[21] Jackson, C. E., Solomon, S. D., Gerstein, H. C., Zetterstrand, S., Olofsson, B., Michelson, E. L. et. al. (2009). Albuminuria in chronic heart failure: prevalence and prognostic importance. The Lancet, 374 (9689), 543-550. doi: http://doi.org/10.1016/s0140-6736(09)61378-7

[22] Metra, M., Cotter, G., Gheorghiade, M., Dei Cas, L., Voors, A. A. (2012). The role of the kidney in heart failure. European Heart Journal, 33 (17), 2135-2142. doi: http://doi.org/10.1093/eurheartj/ehs205

[23] Sirenko, Yu. M. (2010). Novi mozhlyvosti vyznachennia mikroalbuminurii v klinichnii praktytsi. Arterrialna hipertenziia, 3 (11), 55-57. Available at: http://www.mif-ua.com/archive/article/13069

\title{
ROLE OF THE PERICARDIOSCOPY IN THE TREATMENT OF PERICARDIAL EFFUSION
}

\author{
Yulia Pisklova \\ Department of Cardiac Surgery \\ Zaycev V. T. Institute of General and Urgent Surgery NAMS of Ukraine \\ 1 Balakireva entr., Kharkiv, Ukraine, 61018 \\ yuliapisklova@gmail.com
}

\begin{abstract}
In recent years surgical treatment of pericardial effusion has been favoured by mini-invasive interventions. Pericardioscopy supplements it. In the literature actively discusses its expediency, efficiency and informativeness.

Aim of the study. Analyze our experience of using pericardioscopy during surgical treatment of pericardial effusion using mini-invasive interventions.

Materials and methods. From 2000 to 2017, 92 patients with pericardial effusion were operated in our clinic using mini-invasive interventions. Pericardioscopy was used in 72 (78.26 \%) cases. In 32 (44.44\%) pericardioscopy was performed with subxiphoid pericardiotomy, in 40 (55.56\%) - with thoracoscopy on the right or left side.

Results and discussion. The use of pericardioscopy has allowed to significantly reduce the number of idiopathic pericarditis from $20.0 \%$ to $5.56 \%$ and increase the informativeness of the minimally invasive interventions by $14.44 \%\left(\chi^{2}=4.11\right.$, with $v=1$, $\alpha=5 \%$ ). There is no reliable difference in the number of relapses of the disease.

Conclusions. The use of pericardioscopy during mini-invasive interventions is safe and effective. The method of choice in most cases is subxiphoid non-pleural pericardiotomy with pericardioscopy.

Keywords: pericarditis, pericardioscopy, surgical treatment, minimally invasive.
\end{abstract}

\section{Introduction}

In recent years, the incidence of pericarditis has been rising steadily. The reason for this, according to many authors, is the development of diagnostic and therapeutic technologies and the deterioration of the quality of life of the population $[1,2]$. The most common pericardial pathology is exudative pericarditis of different etiologies. Cases of the initial occurrence of effusion in the pericardium cavity are singular [3, 4]. Their cause in the vast majority are various infectious (viral and bacterial), systemic, autoimmune, neoplasm diseases, injuries, heart disease and pericardium, etc. $[5,6]$. At the same time, to find out the cause of the disease can not always be possible and then they speak about the idiopathic nature of the disease [7, 8]. A large number of idiomatic exudative pericarditis is an urgent and debatable problem, because without identifying and eliminating the root cause, the risk of chronic and recurrent pericardial inflammation is significantly increased $[1,9]$. The level of mortality from exudative pericarditis depends on many factors, including the etiology, the prescription of the process, the severity of the underlying disease and related disorders, 
the timeliness and completeness of diagnosis and treatment, and ranges from $1.1 \%$ for uncomplicated viral to $85-90 \%$ with purulent inflammation of the pericardium $[3,5]$.

Despite the long history of the study of pericardium, the methods for diagnosis and treatment, the choice of method and the extent of surgical intervention remain discursive. Today actively discusses the use of mini-invasive interventions for the treatment of exudative pericarditis [10, 11]. They are attributed to the pleural fenestration of the pericardium through mini-thoracotomy or with thoracoscopy, outside of the pleural subxiphoid pericardiotomy and their variations. They are less traumatic, but not always allow to provide a complete revision, sanitation of the pericardial cavity, to find out the cause of pericarditis $[12,13]$. The use of pericardioscopy is aimed at increasing the informativeness, improving the effectiveness and results of mini-invasive interventions [14, 15].

\section{Aim of the research}

To analyze own experience of use of pericardioscopy during surgical treatment of exudative pericarditis of different etiology with the help of mini-invasive interventions.

\section{Materials and methods}

For the period from 2000 to 2017 in the clinic of the State University "Institute of General and Emergency Surgery named after V. T. Zaitsev of the National Academy of Medical Sciences of Ukraine" 92 patients were operated using mini-invasive interventions for exudative pericarditis of different etiologies. Pericardioscopy was performed in 72 (78.26\%) patients. Subxiphoid non-pleural pericardiotomy with pericardioscopy was performed in 32 (44.44 \%) cases, thoracoscopic left-sided pericardiotomy with pericardioscopy - in 36 (50.0 \%) cases, thoracoscopic right-sided thoracotomy with pericardioscopy - in 4 (5.56 \%) cases.

To evaluate the informativeness and effectiveness of using pericardioscopy during mini-invasive interventions, 2 groups of comparison were formed. The first (main) group was made up of 72 patients who had undergone pericardioscopy during the surgical procedure. The comparison group consisted of 20 patients operated using mini-invasive interventions but without pericardioscopy. Both groups are representative of the gender and age of patients, the degree of heart failure. With the number of degrees of freedom equal to unity $(v=1)$, the probability of differences between the main and the control group is not more than $5 \%(\alpha=5 \%)$, i. e. both groups are random samples of one general population (Table 1).

Table 1

Representation of comparison groups

\begin{tabular}{ccccc}
\hline \multicolumn{2}{c}{ The analyzed indicator } & Main group $(\mathbf{n}=\mathbf{7 2})$ & Control group $(\mathbf{n}=\mathbf{2 0})$ & $\chi^{\mathbf{2}}$ \\
\hline \multirow{2}{*}{ Gender } & Men & 40 & 12 & $0.13^{*}$ \\
& Women & 32 & 8 & $0.10^{*}$ \\
Age (years) & Before 40 & 28 & 7 & 13 \\
Note: $*$ - groups represented at $v=1, \alpha=5 \%$ & 44 & &
\end{tabular}

All surgical interventions were performed under conditions of general anesthesia and artificial ventilation of the lungs. In all cases, the cytological and bacteriological examination of the pericardial effusion, histological examination of the pericardium was performed. In cases where pericardioscopy was used, it was performed using a rigid thoracoscope.

As the evaluation criteria, the possibility and amount of visualization of the heart and pericardium surface, the number of idiopathic cases and the number of relapses of the disease during 6-18 months after the end of treatment in both groups of comparison were used.

\section{Results}

The volume of surgical intervention in all 92 (100\%) cases of exudative pericarditis, regardless of etiology, consists in the disclosure, revision, rehabilitation and drainage of the pericardial cavity from the subxiphoid or oral thoracoscopic access. 
Regardless of access, pericardioscopy was performed by rigid thoracoscope after pericardiotomy, partial pericardiotomy and evacuation of most of the exudate. Exudate was removed partly and gradually to prevent the development of acute right ventricular failure. The biopsy of the pericardium was performed as follows: if pericardioscopy was not performed, then the study sent a pericardial region removed during partial pericardiotomy; pericardioscopy allows you to perform a sighting multiple (from 1 to 5 biopsies) biopsy of the inner surface of the pericardium/epicardium under visual inspection. This made it possible to perform a biopsy, first of all, visually altered areas of the pericardium/epicardium.

The pericardial efficacy information of the effectiveness of the surgical intervention itself depends on the possibility of visualization of the heart organs, the disclosure and review of vascular processes, the discovery of altered sections of the pericardium or epicardium and the implementation of their biopsy. Possibility with pericardioscopy to visualize different areas of the pericardial cavity with various available at mini-invasive interventions is different (Table 2).

Table 2

Visualization of anatomical regions of the heart with a pleural and subxiphoid non-pleural pericardioscopy

\begin{tabular}{|c|c|c|c|c|c|c|}
\hline \multirow[t]{2}{*}{ Anatomic region of the heart } & \multicolumn{2}{|c|}{$\begin{array}{l}\text { Left-sided through pleural } \\
\text { pericardioscopy }\end{array}$} & \multicolumn{2}{|c|}{$\begin{array}{c}\text { Right-sided through pleural } \\
\text { pericardioscopy }\end{array}$} & \multicolumn{2}{|c|}{$\begin{array}{c}\text { Subxiphoid non-pleural } \\
\text { pericardioscopy }\end{array}$} \\
\hline & $\mathbf{N}$ & $\%$ & $\mathbf{N}$ & $\%$ & $\mathbf{N}$ & $\%$ \\
\hline $\begin{array}{l}\text { The front surface of the right } \\
\text { ventricle }\end{array}$ & - & - & - & - & 30 & 93.75 \\
\hline $\begin{array}{l}\text { Diaphragmatic surface of the } \\
\text { right ventricle }\end{array}$ & - & - & - & - & 32 & 100 \\
\hline Right atrial appendage & - & - & 3 & 75 & 28 & 87.50 \\
\hline $\begin{array}{l}\text { The lateral surface of the right } \\
\text { atrium }\end{array}$ & - & - & 4 & 100 & 30 & 93.75 \\
\hline $\begin{array}{l}\text { The lateral surface of the left } \\
\text { ventricle }\end{array}$ & 36 & 100 & - & - & 5 & 15.62 \\
\hline $\begin{array}{l}\text { Diaphragmatic surface of the } \\
\text { left ventricle }\end{array}$ & 11 & 30.56 & - & - & 12 & 37.5 \\
\hline Left atrial appendage & 5 & 13.89 & - & - & 16 & 50 \\
\hline $\begin{array}{l}\text { Aortic root and pulmonary } \\
\text { trunk }\end{array}$ & - & - & - & - & 10 & 31.25 \\
\hline
\end{tabular}

Thus, through pleural thoracoscopic access, one can only visualize a small area of the heart and pericardium around the fenestration from the corresponding side. So, right-sided thoracoscopic pericardioscopy allows you to perform a revision of the surface of the heart and pericardium only in the region of the right atrium. Left-side thoracoscopic pericardioscopy is more informative and allows visualization of the left heart, lateral, and diaphragmatic surfaces of the pericardium. Subxiphoid non-pleural pericardioscopy allows visualization of almost the whole surface of the heart, pericardium, and even major vessels (Fig. 1). It also allows you to revise and split the encoded processes into the pericardial cavity.

In the course of research, subxiphoid non-pleural pericardiotomy with pericardioscopy has proven itself as a priority intervention in the treatment of purulent pericarditis. It provides an opportunity to perform revision, sanitation and drainage of purulent cells under visual control and with a minimal probability of proliferation and generalization of the septic process. This can be done even in patients who are in a difficult condition.

The use of pericardioscopy for revision and sight biopsy allowed, in one case, to diagnose the malignant neoplasm of the pericardium - liposarcoma that sprouted into the cavity of the heart and was not diagnosed during preoperative echocardiography. Sight biopsy of the changed sections of the pericardium and the epicardium under the control of pericardioscopy allowed in 4 cases to 
diagnose wounding of the pericardium, in 3 cases it was metastatic, in one case it was to detect, open and revise the pericarditis encrusted at the back of the heart.

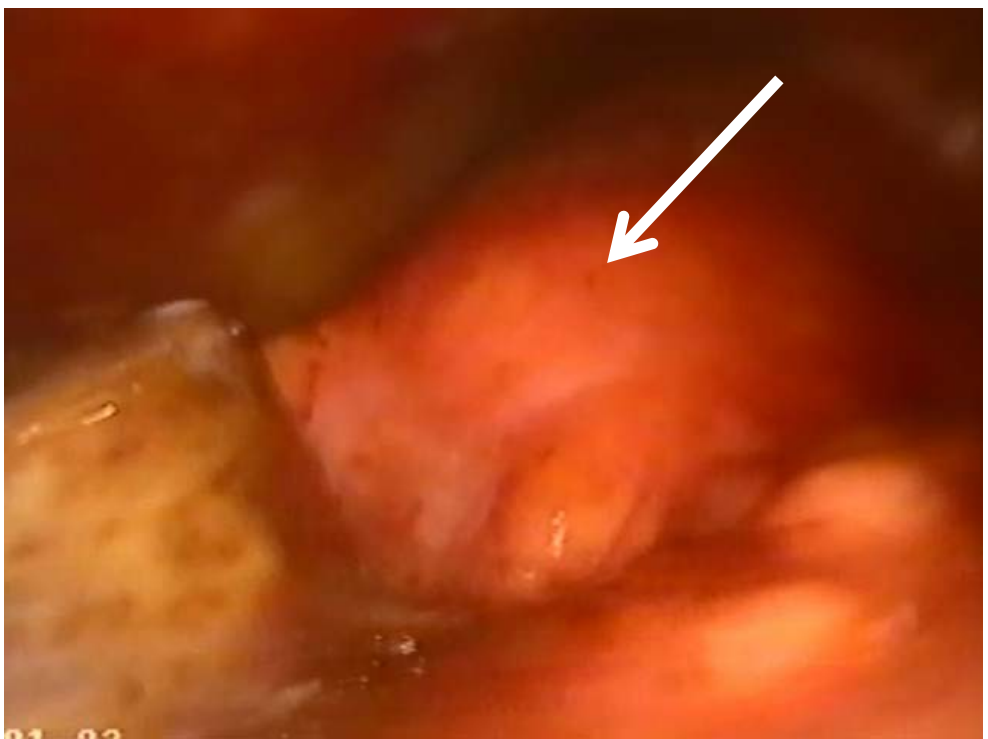

Fig. 1. Visualization of the aortic root (indicated by an arrow) during subxiphoid non-pleural pericardioscopy

The analysis of the results of diagnosis and treatment of patients with exudative pericarditis of different etiologies suggests that the difference in the number of idiopathic cases of this disease is statistically significant (Table 3).

Table 3

The reliability of the difference in the comparison groups by the number of idiopathic and recurrent pericarditis

\begin{tabular}{lcccc}
\hline \multicolumn{2}{c}{ The analyzed indicator } & Main group (n=72) & Control group (n=20) & $\boldsymbol{\chi}^{\mathbf{2}}$ \\
\hline \multirow{2}{*}{ Idiopathic pericarditis } & Yes & 4 & 4 & 4.11 \\
& No & 68 & 16 & $3.64^{*}$
\end{tabular}

Note: * - at $v=1, \alpha=5 \%$

The use of pericardioscopy significantly increases the informativeness of less invasive interventions by $14.44 \%\left(\chi^{2}=4.11\right.$, with $\left.v=1, \alpha=5 \%\right)$ due to the reduction of the number of idiopathic pericarditis from $20.0 \%$ to $5.56 \%$, that is, more than 3 times. The difference in the number of relapses in the two groups is not statistically significant $\left(\chi^{2}=3.64\right.$, with $v=1, \alpha=5 \%$, so, $\left.p<0.05\right)$. There were no complications associated with the use of pericardioscopy among patients. There were no fatalities in both groups for the entire period of the study.

\section{Discussion}

The use of mini-invasive interventions in combination with pericardioscopy is becoming increasingly popular due to the greater specificity and sensitivity of other interventions $[5,12]$. In this case, a large amount of intervention with minimal access with less effect on hemodynamics and general condition of the patient. With the development of technical equipment, virology and molecular biology, the diagnostic value of the epicardium and pericardium is gradually increasing [16, 17]. Sight biopsy of the altered sections of the pericardium is justifiable in cases of tuberculosis, purulent, neoplasm pericarditis and pericarditis, which are not subject to standard treatment methods [18, 19]. 
Despite the great popularity of mini-invasive interventions and pericardioscopy among researchers, there are currently no large randomized trials and clear, proven recommendations for their use [17, 20].

Our studies have shown that mini-invasive interventions, especially non-pleural subxiphoid pericardiotomy, using pericardioscopy are more effective and informative, but in our opinion, the study needs further development involving more patients and expanding the criteria for evaluating the efficacy of pericardioscopy and comparing it with other interventions.

\section{Conclusions}

1. Pericardioscopy allows to perform sanitation, revision, biopsy and drainage of the pericardial cavity under visual control, which significantly expands the volume of surgery while maintaining the minimally invasive access.

2. Use of pericardioscopy during mini-invasive interventions is safe and reliably increases their informativeness by $14.44 \%\left(\chi^{2}=4.11\right.$, with $\left.v=1, \alpha=5 \%\right)$.

3 . The most safe and informative interference with exudative pericarditis, especially purulent, is subxiphoid non-pleural pericardiotomy with pericardioscopy.

\section{References}

[1] Imazio, M. (2012). Treatment of recurrent pericarditis. Expert Review of Cardiovascular Therapy, 10 (9), 1165-1172. doi: http://doi.org/10.1586/erc.12.101

[2] Giryalevskii, S. R. (2004). Diagnostika i lechenie zabolevanij perikarda: sovremennye podhody, osnovannye na dokazatelnoi informacii i klinicheskom opyte [Diagnosis and treatment of pericardial diseases: modern approaches based on evidence and clinical experience]. Moscow: Media Sfera, 132.

[3] Arutyunov, G. P. (2006). Perikardit. Sovremennye problemy diagnostiki i lecheniya [Pericarditis. Modern problems of diagnosis and treatment]. Heart, 8, 384-400.

[4] Sugak, A. B. (2009). Perikardityi: etiologiya, klassifikatsiya, klinika, diagnostika, lechenie. Chast 1 [Pericarditis: etiology, classification, clinic, diagnosis, treatment. Part 1]. Current pediatrics, 8 (2), $77-84$.

[5] Imazio, M., Adler, Y. (2012). Management of pericardial effusion. European Heart Journal, 34 (16), 1186-1197. doi: http://doi.org/10.1093/eurheartj/ehs372

[6] Sugak, A. B., Alekseeva, E. I. (2009). Perikardityi: etiologiya, klassifikatsiya, klinika, diagnostika, lechenie. Chast 2 [Pericarditis: etiology, classification, clinic, diagnosis, treatment. Part 2]. Current pediatrics, 8 (3), 76-81.

[7] Rumbesht, V. V., Diuzhikov, A. A., Kislitskii, A. I., Mozhaev, I. V., Galin, V. A., Mozhaev, N. N. et. al. (2008). Vozmozhnosti differentsialnoy diagnostiki perikarditov neyasnogo proishozhdeniya [Differential diagnostics possibilities for pericarditis with unclear genesis]. Cardiology and Cardiovascular Surgery, 6, 64-66.

[8] Azam, S., Hoit, B. D. (2010). Treatment of Pericardial Disease. Cardiovascular Therapeutics, 29 (5), 308-314. doi: http://doi.org/10.1111/j.1755-5922.2010.00151.x

[9] Lilly, L. S. (2013). Treatment of Acute and Recurrent Idiopathic Pericarditis. Circulation, 127 (16), 1723-1726. doi: http://doi.org/10.1161/circulationaha.111.066365

[10] Gumrukcuoglu, H. A., Odabasi, D., Akdag, S., Ekim, H. (2011). Management of Cardiac Tamponade: A Comperative Study between Echo-Guided Pericardiocentesis and Surgery-A Report of 100 Patients. Cardiology Research and Practice, 2011, 1-7. doi: http://doi.org/10.4061/2011/197838

[11] Haponiuk, I., Kwasniak, E., Chojnicki, M., Jaworski, R., Steffens, M., Sendrowska, A. et. al. (2015). Minimally invasive transxiphoid approach for management of pediatric cardiac tamponade one center's experience. Videosurgery and Other Miniinvasive Techniques, 10 (1), 107-114. doi: http:// doi.org/10.5114/wiitm.2014.47690

[12] Sulimanov, R. R., Sulimanov, R. A. (2013). Sravnitelnyiy analiz maloinvazivnyih hirurgicheskih metodov lecheniya vyipotnogo perikardita [Comparative analysis of minimally invasive surgical methods for treating effeminate pericarditis]. Bulletin of Novgorod State University, 71 (1), 47-50.

[13] Mayosi, B. M. (2009). Interventions for tuberculous pericarditis (review). Cape Town: Wiley, 22.

[14] Aivazyan, S. A., Medvedev, A. P., Sidorov, M. A., Nemirova, S. V., Rybinsky, A. D., Kosonogov, A. Ya. (2011). Perikardioskopiya v differentsialnoy diagnostike i lechenii ekssudativnyih perikarditov 
[Pericardioscopy in differential and treatment of pericardial effusion]. Modern Technologies in Medicine, 2011, 62-65.

[15] Nikonenko, A. S., Zavgorodniy, S. N., Gubka, A. V., Golovko, N. G., Klimenko, A. V., Osaulenko, V. V. et. al. (2011). Hirurgicheskoe lechenie bolnyih ostryim ekssudativnyim perikarditom i ugrozoy razvitiya tamponadyi serdtsa s primeneniem miniinvazivnyih tehnologiy [Surgical treatment of patients with acute exudative pericarditis and threat of development of cardiac tamponade with the use of minimally invasive technologies]. Modern medical technologies, 3-4, 449-450.

[16] Seterovic, P. M., Ristic, A. D., Maksimovic, R., Tatic, V., Ostojic, M., Kanjuh, V. (2003). Diagnostic Value of Pericardial Biopsy: Improvement With Extensive Sampling Enabled by Pericardioscopy. Circulation, 107 (7), 978-983. doi: http://doi.org/10.1161/01.cir.0000051366.97361.ea

[17] Adler, Y., Charron, P., Imazio, M., Badano, L., Barón-Esquivias, G., Bogaert, J. et. al. (2015). 2015 ESC Guidelines for the diagnosis and management of pericardial diseases. European Heart Journal, 36 (42), 2921-2964. doi: http://doi.org/10.1093/eurheartj/ehv318

[18] Maisch, B., Rupp, H., Ristic, A., Pankuweit, S. (2013). Pericardioscopy and epi- and pericardial biopsy - a new window to the heart improving etiological diagnoses and permitting targeted intrapericardial therapy. Heart Failure Reviews, 18 (3), 317-328. doi: http://doi.org/10.1007/s10741-013-9382-y

[19] Maisch, B., Rupp, H., Ristic, A., Pankuweit, S. (2013). Pericardioscopy and epi- and pericardial biopsy - a new window to the heart improving etiological diagnoses and permitting targeted intrapericardial therapy. Heart Failure Reviews, 18 (3), 317-328. doi: http://doi.org/10.1007/s10741-013-9382-y

[20] Khandaker, M. H., Espinosa, R. E., Nishimura, R. A., Sinak, L. J., Hayes, S. N., Melduni, R. M., Oh, J. K. (2010). Pericardial Disease: Diagnosis and Management. Mayo Clinic Proceedings, 85 (6), 572-593. doi: http://doi.org/10.4065/mcp.2010.0046

\title{
INDICATORS OF RESPIRATORY SYSTEM IN CONDITIONS OF CHRONIC ACTION OF HARMFUL ENVIRONMENTAL FACTORS WITH TYPE OF BODY CONSTITUTION
}

\author{
Volodymyr Pshybelsky \\ Department of Human Health and Physical Rehabilitation \\ Private Higher Educational Institution "Academy of Recreational Technologies and Law" \\ $9 b$ Kivertsivska str., Lutsk, Ukraine, 43000 \\ ukr_vol1@ukr.net \\ Oleksandr Zhuravlov \\ Department of Human and Animal Physiology \\ Lesya Ukrainka Eastern European National University \\ 9 Potapova str., Lutsk, Ukraine, 43025 \\ zhuravlov.oleksandr@eenu.enu.ua \\ Tetiana Shevchuk \\ Department of Human and Animal Physiology \\ Lesya Ukrainka Eastern European National University \\ 9 Potapova str., Lutsk, Ukraine, 43025 \\ tetyana_shevchuk_2013@ukr.net \\ Olena Zhuravlova \\ Department of General and Social Phychology and Sociology \\ Lesya Ukrainka Eastern European National University \\ 9 Potapova str., Lutsk, Ukraine, 43025 \\ aln.frolova@gmail.com
}

